\title{
TITLE:
}

\section{ON THE FORMATION OF MEDUSA BUDS IN PROBOSCIDACTYLA ORNATA}

AUTHOR(S):

Uchida, Tohru; Sugiura, Yasuo

\section{CITATION:}

Uchida, Tohru ...[et al]. ON THE FORMATION OF MEDUSA BUDS IN PROBOSCIDACTYLA ORNATA. PUBLICATIONS OF THE SETO MARINE BIOLOGICAL LABORATORY 1975, 22(5): 347-354

ISSUE DATE:

1975-11-29

URL:

http://hdl.handle.net/2433/175894

RIGHT: 


\title{
ON THE FORMATION OF MEDUSA BUDS IN PROBOSCIDACTYLA ORNATA
}

\author{
TOHRU UCHIDA \\ Biological Laboratory, Imperial Household, Tokyo \\ and \\ YASUO SUGIURA \\ Laboratory of Biology, Dokkyo University, Soka-shi, Saitama-ken
}

With Text-figures $1-12$

The medusa of Proboscidactyla ornata has been known to be widely distributed in the tropical and warm waters of the Indo-Pacific and Atlantic Oceans, and it was first described from Japanese waters by Maas (1909) under the name of Proboscidactyla flavicirrata var. stolonifera and later by Uchida (1925) as Proboscidactyla ornata and further in 1927 as Proboscidactyla ornata var. gemmifera. In other parts of the world seas, the medusa has been described by several other investigators such as Fewks, Browne, Bigelow, Vanhöffen, Maas and Kramp etc., and Kramp (1957, 1959, 1965, 1968) who examined many specimens of various stages from different localities, came to the conclusion that Proboscidactyla ornata, Proboscidactyla ornata var. gemmifera, Proboscidactyla flavicirrata var. stolonifera and Proboscidactyla ornata var. stolonifera must be all reduced to the single species Proboscidactyla ornata. The present authors agree with Kramp in supporting this conclusion and here want to demonstrate this by describing the details of the developmental changes in the medusa. The specimens here dealt with were all collected at Misaki, Kanagawa Prefecture from April 1970 to November 1975. With regard to the life-history of the species, Brinckmann-Voss and Vannucci (1965) have confirmed already that the polyp of this medusa is of Lar form as in Proboscidactyla flavicirrata distributed in the northern Pacific.

\section{Morphological Changes}

The medusae captured at Misaki are all in young stages but two. Their size and shape are as follows (Fig. 1). Umbrella somewhat lower than hemisphere, though Mayer (1910) described "slightly higher" in the medusae of $5 \mathrm{~mm}$ in diameter. Bell dome-like, with a slight constriction around the base of the apical portion, size ranging between $1.2 \mathrm{~mm}$ wide $\times 1.0 \mathrm{~mm}$ high and $1.8 \mathrm{~mm}$ wide $\times 1.7 \mathrm{~mm}$ high, and with

Publ. Seto Mar. Biol. Lab., XXII (5), 347-354, 1975.

(Article 25) 


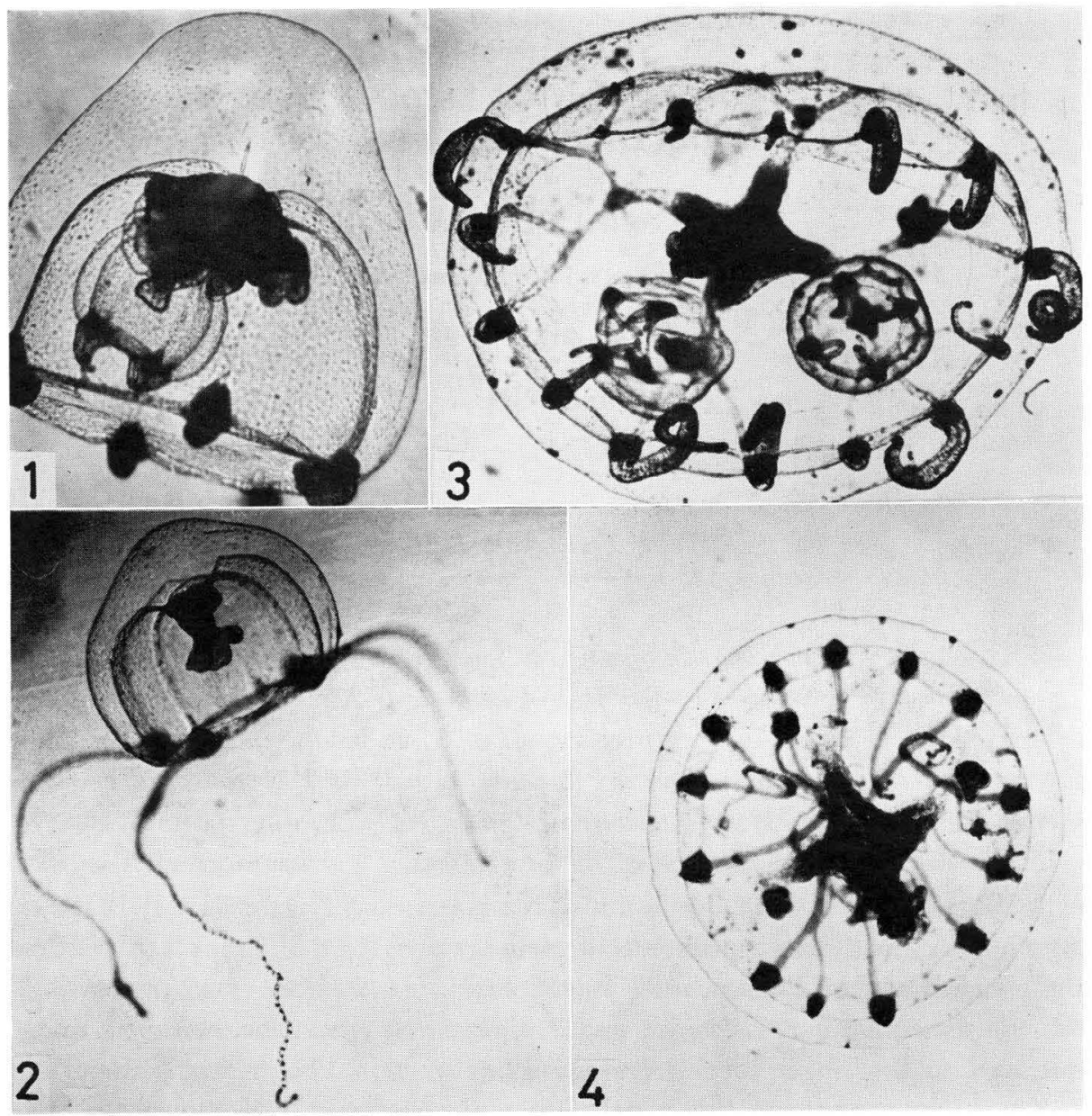

Fig. 1. Side view of a young medusa with a fully developed and many still growing medusa buds ( $1.5 \mathrm{~mm}$ wide).

Fig. 2. Young medusa with fully extended marginal tentacles, showing nematocyst batteries (1.4 mm wide).

Fig. 3. Oral view of a well developed medusa having three medusa buds at forking sites of radial canals $(3.2 \mathrm{~mm}$ wide).

Fig. 4. Aboral view of the other well developed medusa with medusa buds on radial canals ( $2.9 \mathrm{~mm}$ wide).

fairly thick jelly of the umbrella. About $60 \%$ of medusae are provided with four primary radial canals, while about $20 \%$ with five to seven canals and about $20 \%$ with eight canals; and a young medusa exceptionally with nine canals. When the medusae are observed from the aboral side, the secondary radial canals are seemingly issued from the primary canals in the anticlockwise direction (Fig. 5). This is evidently against the Mayer's description (1910) showing that the secondary radial canals are issued from the base of primary radial canals just near the manubrium. The secondary canals are not always issued synchronously. The first bifurcation of 


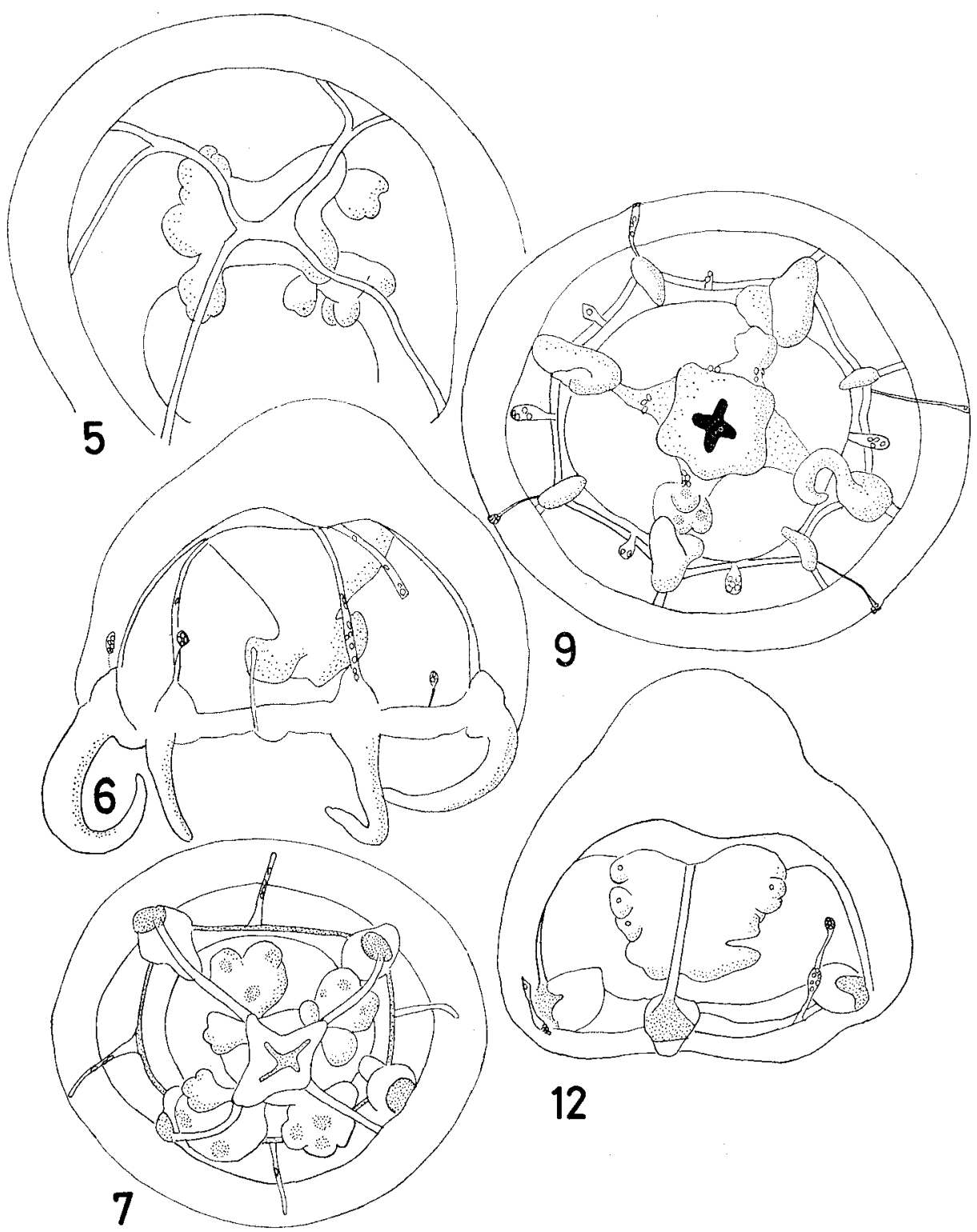

Fig. 5. Aboral view of a medusa showing branches of radial canals. Young medusa buds arising from the four perradial corners of the stomach ( $1.8 \mathrm{~mm}$ wide).

Fig. 6. A newly branched canal in extension (1.5 $\mathrm{mm}$ wide).

Fig. 7. Aboral view of a young medusa with four elongated nematocyst canals and medusa buds in various developmental stages (1.3 mm wide).

Fig. 9. Oral view of a young medusa with four interradial and six adradial nematocyst canals; formation of medusa buds beginning on the opposite sides of the stomach in a perradial axis (1.6 mm wide).

Fig. 12. Small, $1.3 \mathrm{~mm}$ wide, female medusa with only four radial canals, but with fully matured ova. 
primary radial canals is observed in medusae about $1.4 \mathrm{~mm}$ in diameter, in some medusae some secondary canals branched off from the primary ones are found still extending centrifugally towards the umbrellar margin (Fig. 6). No ring canal observed. Tentacle bulbs are black and always develop at the junction of radial canals and the umbrellar margin. The earlier the radial canals are completed, the larger are the bulbs. Tentacles are liable to contract, but sometimes may extend two or three times as long as the umbrellar height, and on such extended tentacles are easily seen nematocyst batteries (Fig. 2). A nematocyst canal usually occurs between each pair of tentacle bulbs. The canals assume each a small nematocyst sac in very young medusae, but with the growth of medusae respective sacs are elongated centripetally to form a tube (Fig. 7). The nematocysts are not distributed uniformly in the tube, but generally accumulated at the terminal portion and the middle of the
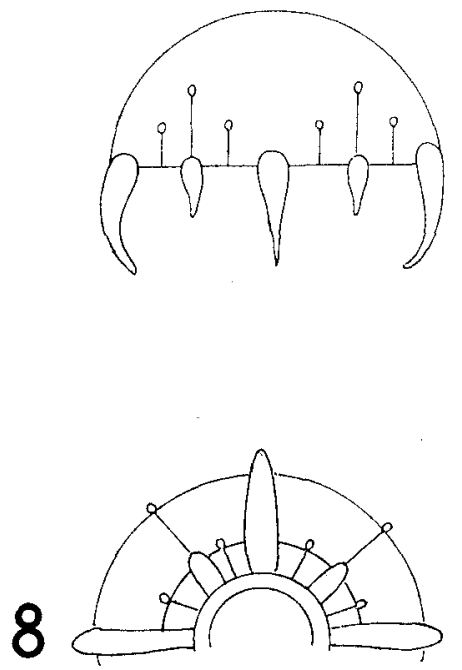

Fig. 8. Schema showing the typical arrangement of nematocyst canals in a medusa of eight tentacle stage.

tube, forming a few nodules. There are only four interradial nematocyst canals in the youngest medusae smaller than $1.3 \mathrm{~mm}$ wide, but the additional adradial canals begin to appear in young medusae provided with four or more radial canals so that the medusae are ultimately, typically, furnished with twelve nematocyst canals in all, three canals per quadrant (Fig. 8). Actually, however, the nematocyst canals in this medusa are mostly less than twelve, because of disappearance of some of them. The disappearance in general takes place at the site of formation of tentacles, where the radial canal reaches the umbrellar margin, although there can be some tentacles accompanied with a nematocyst canal as seen in some medusae with eight tentacles, sometimes provided with long nematocyst canals extending centripetally from the base of four newly formed tentacles (Fig. 9); possibly this shows only the delay of disappearance of nematocyst canals. Manubrium comparatively thick, terminated 
in four crenulated lips, and reaching near the level of the velar opening but never over it.

Two of the examined medusae are large, well developed and furnished with medusa buds; one $3.2 \mathrm{~mm}$ and the other $2.9 \mathrm{~mm}$ wide. The former has fifteen radial canals (3-4-3-5), the same number of tentacles and nematocyst canals each having one or two nodules (Fig. 3). The latter has sixteen radial canals (4-44-4), sixteen tentacles and seventeen nematocyst canals each having one or two nodules (Figs. 4, 10,11).

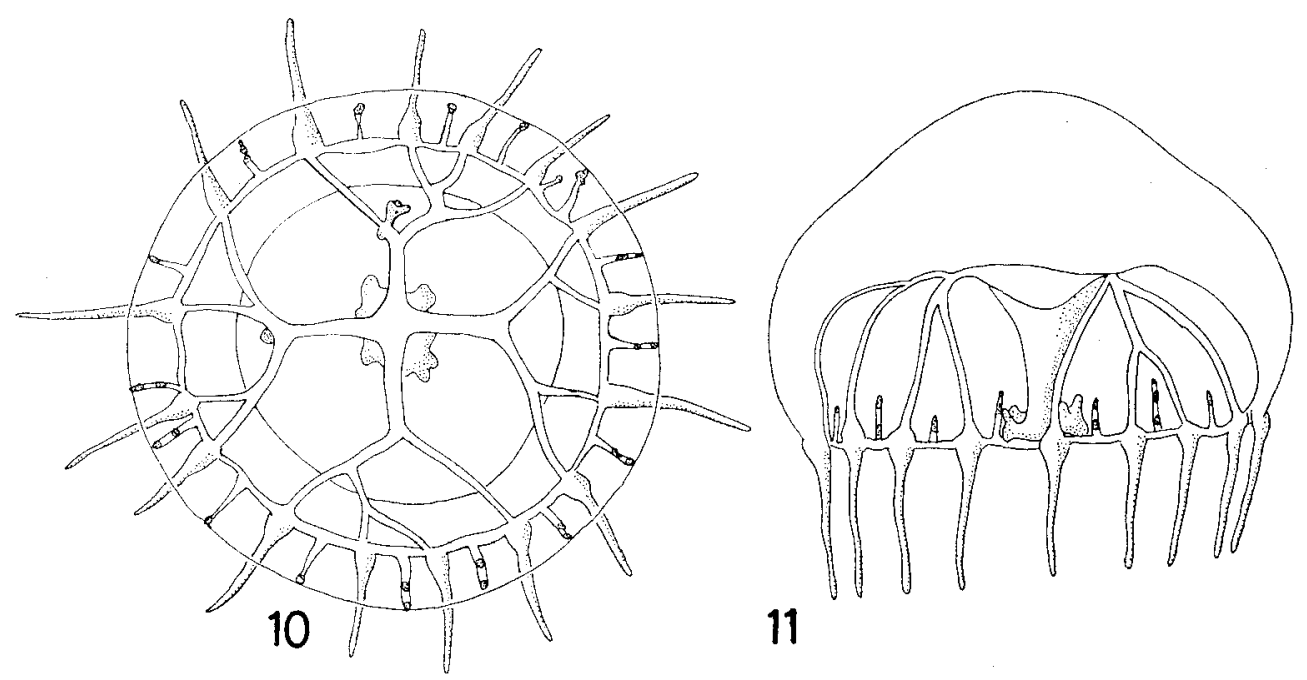

Fig. 10. Aboral view of a fully developed medusa with a medusa bud and a rudimentary one on radial canals, after 18 days of rearing ( $4.0 \mathrm{~mm}$ wide).

Fig. 11. Side view of the same medusa.

\section{Bud Formation}

Medusa buds arise in clusters from four perradial corners of the stomach in young specimens (Figs. 5, 7, 9); while in the two large specimens just referred to above, they are attached to the point of the first forking of primary radial canals as Kramp $(1959,1965,1968)$ described (Figs. 3, 4, 10). No buds are formed yet in newly liberated medusae or those not yet separated from the mother. The smallest medusa having buds is so far $0.9 \mathrm{~mm}$ wide and medusae over $1.2 \mathrm{~mm}$ wide are usually provided with buds. The buds start as a minute globular medusa-nucleus, measuring only $0.1 \mathrm{~mm}$ in diameter, but take the shape of juvenile medusa bud very soon (Fig. 7), which is provided with four swellings respectively marked with a brownish rudiment of the tentacle bulb. However, morphological changes of the medusa bud are not so distinct that clustered buds look quite similar in shape but different only in size. Nematocysts contained in a sac are distinguishable already in the medusa bud of $0.3 \mathrm{~mm}$ wide. Medusa buds in full size are about $0.5 \mathrm{~mm}$ wide and provided with four thick radial canals, short tentacles, nematocyst sacs containing several nematocysts 
and a fairly developed manubrium. The number of buds in respective medusae varies considerably, none to eighteen, however the number of buds found at each stomach corner in respective medusae is almost similar.

In two larger medusae, medusa buds seem to arise directly from the sites of the first or second forking of radial canals. In the $3.2 \mathrm{~mm}$ wide medusa, two buds are found at the first and one bud at the second forking; while in the other $2.9 \mathrm{~mm}$ wide medusa, three buds are respectively attached to the canal at or near the first forking as well as at the second by a short stalk.

\section{Gonad Formation}

According to Mayer (1910) "No gonads have been observed upon the manubrium of the gemmifera form", but the present authors have observed the gonad on the interradial portions of the manubrium in three specimens still in very young stages. Thus, two females, $1.3 \mathrm{~mm}$ (A) and $1.5 \mathrm{~mm}(\mathrm{~B})$, and one male, $1.3 \mathrm{~mm}(\mathrm{C})$ in umbrella diameter, were found in the material. Ova are very large in size (Fig. 12), and the gonad seems to develop regardless of the formation of medusa buds. Actually, the medusa buds were found in two of the above-mentioned three medusae; 5 buds in the specimen B and a single bud in the specimen C. In spite of their larger size, the two medusae, $2.5 \mathrm{~mm}$ and $4.0 \mathrm{~mm}$ in diameter respectively, were quite devoid of gonads.

\section{Seasonal Occurrences}

The collection of surface plankton has been continued once a week in the period from April, 1970 to November, 1975 at the entrance of Aburatsubo Bay, Misaki. The date and water temperature at the time of appearance and disappearance of this medusa are shown in Table I. None of medusa was captured in 1974. The date and water temperature at the time of occurrences of medusae with gonads are: September 25,1973 and $24.2^{\circ} \mathrm{C}$ for the specimen $\mathrm{A}$, October 1,1972 and $20.8^{\circ} \mathrm{C}$ for the specimen B, and October 4,1970 and $21.3^{\circ} \mathrm{C}$ for the specimen C. From these data, it may be seen that the occurrences are concentrated in the later part of the occurring season of this medusa. The date and water temperature at the occurrences of the two larger

Table 1. The date and water temperature at the appearance and disappearance of Proboscidactyla ornata in the years 1970-75.

\begin{tabular}{cllll}
\hline & \multicolumn{2}{c}{ Appearance } & \multicolumn{2}{c}{ Disappearance } \\
\hline 1970 & August 15 & $\left(25.6^{\circ} \mathrm{C}\right)$ & October 4 & $\left(21.3^{\circ} \mathrm{C}\right)$ \\
1971 & September 26 & $\left(23.8^{\circ} \mathrm{C}\right)$ & October 3 & $\left(22.2^{\circ} \mathrm{C}\right)$ \\
1972 & August 6 & $\left(25.5^{\circ} \mathrm{C}\right)$ & October 1 & $\left(20.8^{\circ} \mathrm{C}\right)$ \\
1973 & May 20 & $\left(18.5^{\circ} \mathrm{C}\right)$ & October 30 & $\left(19.0^{\circ} \mathrm{C}\right)$ \\
1974 & & - no occurrence- & & \\
1975 & September 7 & $\left(25.2^{\circ} \mathrm{C}\right)$ & September 28 & $\left(22.4^{\circ} \mathrm{C}\right)$ \\
\hline
\end{tabular}


medusae, $3.2 \mathrm{~mm}$ and $2.9 \mathrm{~mm}$ in umbrella diameter respectively, were October 18, 1973 and $22.2^{\circ} \mathrm{C}$ and September 25,1973 and $24.2^{\circ} \mathrm{C}$ respectively, and this shows also that these occurred in the later part of the season.

\section{Remarks}

The medusae captured at Misaki during these five years were mostly young ones. The medusa, Proboscidactyla flavicirrata var. stolonifera, reported by Maas (1909) from Japan is also a young one. Uchida (1927) describes on Proboscidactyla ornata var. gemmifera "The variety is very similar to Proboscidactyla ornata but differs in the presence of medusa buds on the manubrium." and Kramp (1965) states "All developmental stages, some newly liberated, with only four tentacles, some without medusa buds ("ornata"), many with buds on the radial canal ("tropica"), or on the lateral walls of the stomach ("gemmifera")". The medusae examined by the present authors possess also medusa buds except a few specimens, which arise from the lateral wall of the stomach, and any morphological differences cannot be found between the medusae with and without medusa buds.

On the other hand, only two large medusae were found in the material. Judging from the number of radial canals, tentacles and nematocyst canals, they seem each to be nearly a complete medusa, but lack gonads. Medusa buds are arising in these medusae from the sites of the first or second forking of radial canals, and this agrees with the previous descriptions of Maas (1905) on Proboscidactyla flavicirrata var. stolonifera, of Mayer (1910) on Proboscidactyla ornata var. stolonifera and of Kramp (1957) on Proboscidactyla ornata, except in the point that medusa buds arise directly from canals, but not from the blastostyle as was mentioned by Kramp. No gonads were observed in these large medusae, but one of them was possibly provided with rudimentary gonads. Maas (1905) gave the descriptions on well-developed specimens of Proboscidactyla flavicirrata var. stolonifera "vor Eintritt der eigentlichen Geschlechtsreife.", and these Maas' specimens seem to be in the same stage of development as the present two larger specimens from Japanese waters.

\section{Acknowledgments}

The authors wish to express their warm thanks to the director and the staff of the Misaki Marine Biological Station for the use of facilities of the station for the present research.

\section{REFERENCES}

Bigelow, H.B. 1909. The medusae. Memoirs of the Museum of Comparative Zoology at Harvard College. 37.

Brinckmann-Voss, A. and M. Vannucci 1965. On the life-cycle of Proboscidactyla ornata.

Kramp, P.L. 1959. The Hydromedusae of the Atlantic Ocean and Adjacent Waters.

Kramp, P.L. 1961. Synopsis of the Medusae of the World. Jour. Mar. Biol. Ass. U.K..

Kramp, P.L. 1965. The Hydromedusae of the Pacific and Indian Oceans. I.

Kramp, P.L. 1968. The Hydromedusae of the Pacific and Indian Oceans. II and III. 
Maas, O. 1905. Die Craspedoten Medusen der Siboga- Expedition.

Maas, O. 1909. Japanische Medusen. Beiträge zur Naturgeschichte Ostariens.

Mayer, A.G. 1910. Medusae of the world. I.

Uchida, T. 1925. Some Hydromedusae from Northern Japan. Jap. Jour. Zool. 1.

Uchida, T. 1927. Studies on Japanese Hydromedusae. Jour. Fac. Sci. Imp. Univ. Sect. 4. 1. 